В этом отношении сам поиск исторических истоков аналитической философии не сводится к имени одного автора, представляет собой развивающийся во времени процесс со всеми сопутствующими аспектами прогрессивной эволюции, дополнений и влияний.

Подводя итог изученному, следует отметить значимость контаминации для становления традиции «лингвистического кантианства», не ограничивая суть онтологии языка, формирующейся в концепциях и работах философов-аналитиков исключительно под влиянием традиции трансцендентальной эпистемологии. Явление истории философии, обозначенное понятием «лингвистическое кантианство» значительно шире, включает в себя область трансцендентальной логики и функциональной семантики.

Дальнейшее развитие «лингвистического кантианства» включает в себя семантические теории, отдельные теории референции, применение частных аспектов языка, несущих на себе отпечаток влияния кантовского референциализма. Научная значимость результатов проведенного исследования позволяет кардинально пересмотреть картину развития истории философии и распределения границ философских традиций и направлений в пользу формирования нового «лингвистчиеского кантианства», обосновать множество направлений, условно объединенных одним термином «аналитическая философия».

$$
* * *
$$

1. Strawson P. Individuals. New York-London: Routledge Publ., 2006. 255 p.

2. Strawson P. S. The Bounds of Sense: An Essay on Kant's "Critique of Pure Reason". L.: Routledge, 1995. $196 \mathrm{p}$.

3. Quine W. V. O. Ontological Relativity // The Journal of Philosophy. NY: The Journal of Philosophy, Inc., 1968. Vol. 65. № 7. P. 185-212.

4. Суханова Е. Н. Дескриптивная метафизика П. Ф. Стросона в контексте развития аналитической философии : диссертация на соискание ученой степени кандидата философских наук : 09.00.03 / Е. Н. Суханова. - Томск: [б. и.], 2008. - 201 л.

5. Мур Д. Э. Доказательство внешнего мира // Аналитическая философия: избранные тексты / сост. А. Ф. Грязнов. М.: Изд-во МГУ, 1993. С. 66-84.

6. Katz J. J. The philosophy of language. New York-London: Harper and Row, 1966. 327p.

\title{
Токарев Д.А.
}

Гедонистический вариант атрибутивной модели страдания по Аристотелю Омский институт водного транспорта - филиал ФГБОУ ВО «СГУВТ» (Россия, Омск)

doi: $10.18411 / \mathrm{lj}-05-2020-327$

idsp: ljournal-05-2020-327

\section{Аннотация}

В статье рассматривается гедонистический вариант атрибутивной модели страдания на основе философских взглядов Аристотеля. Проанализированы различные источники и литература, в которых, так или иначе, затрагивается проблема страдания и гедонистический вариант его преодоления. Подчеркивается тесная связь страдания и удовольствия с нравственной добродетелью. Страдание как преодоление себя.

Ключевые слова: Страдание, гедонизм, атрибут, Аристотель, нравственная добродетель, телесные удовольствия и духовные страдания, мужество и дружелюбие.

\section{Abstract}

The article considers a hedonistic version of the attributive model of suffering based on the philosophical views of Aristotle. Various sources and literature have been analyzed from the point of view of the problem of suffering and the hedonistic version of its 
overcoming. The close connection of suffering and pleasure with ethical virtue is emphasized. Suffering is seen as overcoming oneself.

Keywords: Suffering, hedonism, attribute, Aristotle, ethical virtue, carnal pleasure and spiritual suffering, courage and friendliness.

При рассмотрении проблемы страдания необходимо делать упор не на физическом его проявлении, а на внутренних переживаниях человека, которые заставляют человека либо мириться с физической болью, либо преодолевать ее, при этом осмысливая свое предназначение в этом мире. В этом случае следует определить, что страдание - одно из важных состояний позволяющее человеку осмыслить свое существование в этом мире, следовательно, необходимо выяснить, какие есть модели страдания и как они формулируют жизненные смыслы страдания. Человек часто пытается вырваться за рамки земной жизни и делает все, чтобы реализовать любой ценой свое предназначение в исключительности другой жизни. Доминирование стремления к индивидуальному самоутверждению ведет по необходимости к тому, что ценность жизни отступает перед этим последовательным антропоцентризмом. Это можно видеть в буддизме, для которого жизнь ценна только своим растворением в вечном мире. В более острой форме эта сторона дела обнаруживается в европейской культуре, начиная с античного гедонизма. Отступление от фундаментальной ценности жизни, неизбежное в мирочувствовании гедонизма, принимает со временем в западной культуре вполне определенный поворот, именно смерть уравнивается с жизнью, и интеллектуалы Запада начинают говорить о витальном и танатальном стремлениях как изначально заложенных в природе человека. Есть некая иррациональная логика, порождающая танатальную окраску мировоззренческого антропоцентризма.

В рамках атрибутивной модели страдание предстает как обязательный атрибут земной жизни человека, вследствие чего страдание прекращается только при ситуации ухода из жизни. Нет жизни - нет и страдания.

Определив основные характеристики танатального варианта атрибутивной модели страдания необходимо обратиться к следующему варианту данной модели гедонистическому, для которого представление о страдании связано с проявлением отсутствия удовольствия. При анализе этого варианта страдания стоит отметить, что представительство философов и направлений, которых можно отнести к этой позиции, довольно широко и охватывает большой временной период, от античности до современных авторов. Еще важно отметить непростую задачу выявления общей позиции в рамках гедонистического варианта по отношению к возможности преодоления страдания. Отношение страдания и удовольствия проявляется по-разному, в одном случае, усиление удовольствия для уменьшения страдания, в другом взаимный переход от страдания к удовольствию, от удовольствия к страданию, в третьем случае, необходимо получать яркие и непродолжительные удовольствия, но быть готовым за это заплатить долгими страданиями. Все это на фоне одного главного условия - пока жизнь продолжается, то продолжается и страдание в тесном контакте с удовольствием. Данный вариант многолик по трактовке соотношения страдания и удовольствия, но в определении жизненного смысла страдания преобладает позиция атрибутивности, что приводит к некоторой обреченности по отношению к самой жизни и к чрезмерному стремлению к удовольствию как способу избавления от страдания.

Важным, в рамках гедонистического варианта атрибутивной модели, представляется мнение о страдании Аристотеля, который, противопоставляя страданию удовольствие, считает, что отсутствие страдания уже само по себе есть удовольствие. «Удовольствие противостоит страданию и отсутствию страдания так же, как большее противостоит меньшему и равному...». Страдание может притупить восприятие чеголибо приятного, тогда как удовольствие изгоняет страдание. При этом, по мнению Аристотеля, неважно противоположно ли оно как раз данному страданию или это 
первое попавшееся удовольствие, будь оно только достаточно сильным. Аристотель считает, что страдание - нехватка чего-то природного, а удовольствие - его восполнение. К примеру, почувствовав сначала нехватку пищи и, испытав из-за этого страдание, люди получают удовольствие от восприятия. «Природа, очевидно, прежде всего, избегает того, что доставляет страдание, стремится же к тому, что доставляет удовольствие». Аристотель склонен расценивать удовольствие как необходимое в жизни человека удовлетворение потребностей и обретения сил, но при этом любое удовольствие требует испытания страданием. Зависимость человека от меры удовольствия и силы страдания приводит к стремлению освободиться от этого жизненного круга.

Страдания и удовольствия часто в Греции связывали с добродетелью. Так, Аристотель рассматривает телесные удовольствия и страдания, проводя анализ нравственных добродетелей. Анализируя мыслительные добродетели, он трактует духовные удовольствия и страдания как связанные с созерцанием, мышлением. Духовные страдания, муки души у Аристотеля не рассматриваются как нечто отдельное от телесных страданий. Давая определение нравственной добродетели, Аристотель пишет, что - «это способность поступать наилучшим образом во всем, что касается удовольствий и страданий...». Он считает, что «три вещи мы избираем и трех избегаем: первые три - это прекрасное, полезное и доставляющее удовольствие, а вторые противоположны этому - постыдное, вредное, доставляющее страдание; во всем этом добродетельный поступает правильно, а порочный оступается, причем главным образом в связи с удовольствием».

Итак, удовольствия и страдания являются мерилом в поступках людей. Объясняя свою позицию, Аристотель пишет, что, во-первых, нравственная добродетель сказывается в удовольствиях и страданиях: ибо если дурно мы поступаем ради удовольствия, то и от прекрасных поступков уклоняемся из-за страданий. Во-вторых, добродетели связаны с поступками и страстями, а всякая страсть и всякий поступок сопровождается удовольствием или страданием, уже поэтому нравственная добродетель связана с удовольствием или страданием. И, в-третьих, эту связь показывают и наказания, ибо это своего рода лекарства, а лекарства по своей природе противоположны заболеванию.

Касаясь этической специфики гедонистической позиции Аристотеля необходимо рассмотреть следующие утверждения философа. Одной из важнейших добродетелей он считает мужество. Определяя мужество в отношении к страданию, боли и удовольствию, Аристотель называет мужественным того, кто стойко переносит страдания: «мужество сопряжено со страданиями и ему по праву воздают хвалу; в самом деле, переносить страдания тяжелей, чем воздерживаться от удовольствий». Мужественный человек не ищет страданий и ран, которые причиняют ему душевную и физическую боль, но и не избегает их.

Что касается щедрости в сопряжении со страданием, то для добродетельного человека отклонение от правильного поведения всегда мучительней материальной потери, поэтому даяние не может заставить страдать. «Это доставляет ему удовольствие и не приносит страдания, ибо согласное с добродетелью или доставляет удовольствие, или не причиняет страданий». Но кто, давая, страдает, не может быть назван щедрым.

Страдания и удовольствия, возникающие при общении, по мнению Аристотеля, связаны с таким душевным складом как дружелюбие. Дружелюбный человек будет стараться не доставлять страданий или доставлять удовольствие. Предпочтение он отдает доставлению удовольствия, но, принимая во внимание нравственную красоту и пользу. Таким образом, ради большего удовольствия впоследствии он заставит немного пострадать. 
Отношение человека к чужой беде или радости также отражает его способность к страданию. Кто склонен к негодованию - страдает, видя незаслуженно благоденствующего. Завистливого человека заставляет страдать все хорошее. А злорадный настолько лишен способности страдать и сострадать, что радуется чужой беде.

Аристотель пишет о страдании как о преодолении себя, и при этом практически провозглашает страдание жизненным принципом, заложенным в самом естестве. Здесь он ссылается на точку зрения «природоведов», считающих, что любое действие живого существа требует напряжения, усилия, тем самым является страданием: видеть и слышать равносильно страданию, только мы с этим свыклись. Страдание и удовольствие присущи жизни, но если человек больше страдает, то, возможно, он будет стремиться к скорейшему уходу от этой жизни, в надежде на иное состояние с преимуществом удовольствия. Аристотель прослеживает диалектику страдания и удовольствия, отмечая возможность их взаимодействия и взаимоперехода. Атрибутивное понимание страдания в рассуждениях древнегреческих мыслителей довольно сильно уводит нас от истинных переживаний человека. Страдание в данном случае просто констатируется и рационально объясняется как антипод удовольствия, а почему люди по-разному переживают страдания, почему для одних жизнь - источник вечности, а для других лишь мгновение в бездне небытия? Отличительность атрибутивных вариантов состоит в необходимости либо получения большего числа удовольствий, либо в уходе от самой жизни, ведь нельзя же преодолеть страдание, которое само по себе является составляющим жизни.

$$
* * *
$$

1. Аристотель. Собрание сочинений в 4-х томах. Т.4. Никомахова этика. / Аристотель. - М.: Мысль, 1984. - 326c.

2. Антология мировой философии: в 4 т. - М.: Мысль, 1969. - 1587 с.

3. Токарев Д.А. Атрибутивность гедонистического варианта страдания // Сборник научных трудов, по материалам XIV международной научно-практической конференции 01.10.2018 г. - Изд. ЦНК MOAH, 2018.

\section{Барруху С.Ф. \\ Экологические парадигмы через призму философского мировоззрения}

ФГБОУ ВО «Воронежский государственный лесотехнический университет имени Г.Ф. Морозова»

(Россия, Воронеж)

doi: $10.18411 / \mathrm{j}-05-2020-328$

idsp: ljournal-05-2020-328

Научный руководитель Фесикова О.В.

\section{Аннотация}

В статье автор рассматривает как именно философское мировоззрение реагирует и отвечает на новые проблемы современного мира, такие как техногенное влияние на окружающую среду и вмешательство в экосистему. Так же рассматривается роль философии для экологического вопроса.

Ключевые слова: философия, экология, человек, мировоззрение, общество, глобализация.

\section{Abstract}

In the article, the author examines exactly how the philosophical worldview responds and responds to new problems of the modern world, such as the technogenic impact on the 